\title{
Electric Field (EF) in the Core of the Electrochemical (EC) Disinfection
}

\author{
Djamel Ghernaout ${ }^{1,2}$ \\ ${ }^{1}$ Chemical Engineering Department, College of Engineering, University of Ha'il, Ha'il, KSA \\ ${ }^{2}$ Chemical Engineering Department, Faculty of Engineering, University of Blida, Blida, Algeria \\ Email: djamel_andalus@hotmail.com
}

How to cite this paper: Ghernaout, D. (2020) Electric Field (EF) in the Core of the Electrochemical (EC) Disinfection. Open Access Library Journal, 7: e6587.

https://doi.org/10.4236/oalib.1106587

Received: July 6, 2020

Accepted: July 25, 2020

Published: July 28, 2020

Copyright () 2020 by author(s) and Open Access Library Inc.

This work is licensed under the Creative Commons Attribution International License (CC BY 4.0).

http://creativecommons.org/licenses/by/4.0/ (c) (i) Open Access

\begin{abstract}
Killing pathogens by different electrochemical (EC) disinfection means has been largely reported in the literature, even if the influence of process variables and reactor conception on kill performance has not been well comprehended. This review concentrates on EC microbial killing mechanisms especially the free radicals' contribution and the effect of the electric field (EF), which are by their nature poisonous to microbes. Some mechanisms have been suggested to interpret the deadliness of EC application. Such pathways comprise: 1) oxidative stress and cell loss of life because of electrochemically produced oxidants, 2) irreversible permeabilization of cell membranes by the placed EF, 3) electrooxidation of vital cellular constituents during exposure to electric current or induced EFs, and 4) electrosorption of negatively charged $E$. coli cells to the anode surface followed by direct electron transfer reaction. Future investigations have to be more dedicated to the EF influence in the EC disinfection, as it is the main part of the involved mechanisms. Employing granular activated carbon post-treatment could greatly reduce the concentrations and poisonous effects of disinfection by-products. Moreover, secure multi-barrier techniques, like distillation, plasma discharge, nanotechnologies, and membrane processes remain to be suggested, tested, and industrially encouraged. Despite their limitations, both adsorptive techniques and membrane processes persist to be an encouraging domain of research thanks to their relatively low costs and ease of applications.
\end{abstract}

\section{Subject Areas \\ Chemical Engineering \& Technology}

\section{Keywords}

Electrochemical (EC) Disinfection, Electric Field (EF), Hydroxyl Radical 
$\left({ }^{\bullet} \mathrm{OH}\right)$, Electrocoagulation (ECG), Electrooxidation (EO), Reactive Oxygen Species (ROSs)

\section{Introduction}

Electrochemical (EC) disinfection of water and wastewater has been widely mentioned [1]-[10]. Numerous pathways have been proposed to explain the EC action, including: 1) oxidative stress and cell loss of life due to electrochemically formed oxidants, 2) irreversible permeabilization of cell membranes by the applied electric field (EF), 3) and electrooxidation (EO) of vital cellular constituents during exposure to electric current or induced EFs [11]-[26].

While EF is applied on water carrying microorganisms with plunged electrodes, chemical oxidants are generated [12] [27] [28] [29] [30] [31]. Electrolysis forms numerous oxidants in the occurrence of oxygen $\left(\mathrm{O}_{2}\right)$, comprising hydrogen peroxide $\left(\mathrm{H}_{2} \mathrm{O}_{2}\right)$ and ozone $\left(\mathrm{O}_{3}\right)$, as well as free chlorine $\left(\mathrm{Cl}_{2}\right)$ and chlorine dioxide $\left(\mathrm{ClO}_{2}\right)$ when chloride ions $\left(\mathrm{Cl}^{-}\right)$are existing in water [6] [12] [27] [32]. Such oxidants are mostly accountable for the deadliness of the applied direct current (DC) [27]. Numerous scientists established the synergetic contribution of antimicrobial agents and EF in neutralizing pathogens [6] [33]-[38].

EFs are naturally fatal to cells. This is mainly attributed to the irreversible permeabilization of the cell membrane [39] [40] [41]. Through experiments realized on artificial bi-film lipid membranes it was proved that a membrane exposed to an outer EF collects charge much like a capacitor, and a transmembrane potential is produced [6]. A short-lived steady-state current across the membrane is initiated when the membrane is completely loaded, showing an induced permeability of the membrane to hydrophilic molecules. Such a phenomenon is largely explained by models involving the formation of transient pores in the membrane due to the application of the outer EF. The reversibility of such an electro-permeabilization is influenced by two key factors: The level of the formed transmembrane potential, and the period of application of the outer EF. For cells, transmembrane potentials over $1 \mathrm{~V}$ and longer pulse times lead to irreversible permeabilization and cell dying. The transmembrane potential produced by an outer EF is a function of the size of the cell membrane, with bigger cells experiencing a bigger transmembrane potential from an applied EF. As a result, the level of the field required to kill yeast cells is frequently smaller than that requested to neutralize microbes [13]. Death takes place due to either the apparition of constant pores and following destabilization of the cell membrane or mislaying of crucial cell constituents and demolition of chemical gradients via transport across transient pores [39]. If formed oxidants by EC techniques are existing, these pores could authorize the oxidants open entrance to the inside of the cell, contributing to the demobilization phenomena [42] [43] [44] [45].

EFs possess as well the capability of demolishing cells in the absence of demolishing their membranes. Matsunaga et al. [16] explained a technique in which 
cells were eliminated in the absence of breaking, only a little with the $\mathrm{EO}$ of intracellular coenzyme A [46] [47]. Consequently, EFs can straight oxidize cellular compounds, leading to cell dying [6] [48] [49] [50].

Several researches have been dedicated to the employ of EFs and currents to eliminate bacteria and yeast in industrial and medical applications, as indicated by the next cases. Potable water polluted with Escherichia coli (E. coli) K12 (100 cells $/ \mathrm{cm}^{3}$ ) was disinfected at a rate of 600 cells $/ \mathrm{cm}^{3} / \mathrm{h}$ with the use of a $0.7 \mathrm{~V}$ electric potential using a carbon cloth electrode [16]. Potable water polluted with 335 cells $/ \mathrm{mL}$ total coliforms and 1035 cells $/ \mathrm{mL}$ fecal streptococci was sterilized with a $2.5 \mathrm{~mA} / \mathrm{cm}^{2}$ DC density ( $125 \mathrm{~mA}$ current) applied with $5 \mathrm{~cm} \times 5 \mathrm{~cm}$ titanium electrodes for $30 \mathrm{~min}$ [17]. DC (60 mA) was employed to impede the development of E. coli, Bacillus subtilis, Pseudomonas aeruginosa ( $P$. aeruginosa), and Staphylococcus aureus contaminants of a bioprocess reactor [18]. Grahl and Markl [14] focused on a non-thermal pasteurization technique that can avert to touch the vitamins, enzymes, texture, and taste of treated foods. They followed the impact of pulsed EFs on E. coli and Saccharomyces cerevisiae suspended in milk and fruit juice, respectively [14]. Bacteriophages stay alive short applications to different current magnitudes in an EC cell better than bacteria at both low $\left(1 \times 10^{3}\right.$ colony-forming units $\left.(\mathrm{CFUs}) / \mathrm{mL}\right)$ and high $\left(1 \times 10^{6} \mathrm{CFUs} / \mathrm{mL}\right)$ population density [6]. Electrolyzed water had been found to possess an elevated lethal performance than $\mathrm{Ca}(\mathrm{OCl})_{2}$ of the alike measured active $\mathrm{Cl}_{2}$ dose [51]. During the treating time, fundamentally internal cell constituents of the microorganisms enter in chemical reactions with the disinfectants [52]-[57].

Regardless of the reality that the deactivation of bacteria by different EC disinfection means has been reported in the literature, the influence of process variables and reactor conception on kill performance remain to be fully understood. Further, a small number of researches focused on the mechanisms of EC disinfection. This review concentrates on EC microbial killing mechanisms. Several related and pertinent references are examined and key EC mechanisms are discussed. The effect of electrode material on the pathogens' killing is discussed. The EC disinfection is compared with other methods in terms of performance in neutralizing microbes. Free radicals' contribution to killing pathogenic microorganisms and the EF impact are reviewed. Finally, propositions for better EC disinfection especially in terms of DBPs control are presented.

\section{Influence of Electrode Material on the Microbial Demobilization}

The nature of electrodes has a key role in electrocoagulation (ECG) process. Ghernaout et al. [1] used ordinary steel, stainless steel (SS), and aluminum electrodes. Ordinary steel $(U=12 \mathrm{~V})$ and aluminum $(U=11.8 \mathrm{~V})$ give to the solution $\mathrm{Fe}^{2+}{ }_{\text {(aq) }}$ and $\mathrm{Fe}^{3+}{ }_{\text {(aq) }}($ neutral $\mathrm{pH})$ and $\mathrm{Al}^{3+}{ }_{\text {(aq) }}$, respectively; however, SS ( $U=$ $10.7 \mathrm{~V}$ ) does not produce any metallic ions to the solution. Reduction of cellular concentration at $620 \mathrm{~nm}$ as a function of electrode nature is shown in Figure 1. For the first $10 \mathrm{~min}$ (Figure 1), SS (55.45\%) is less efficient than ordinary steel 


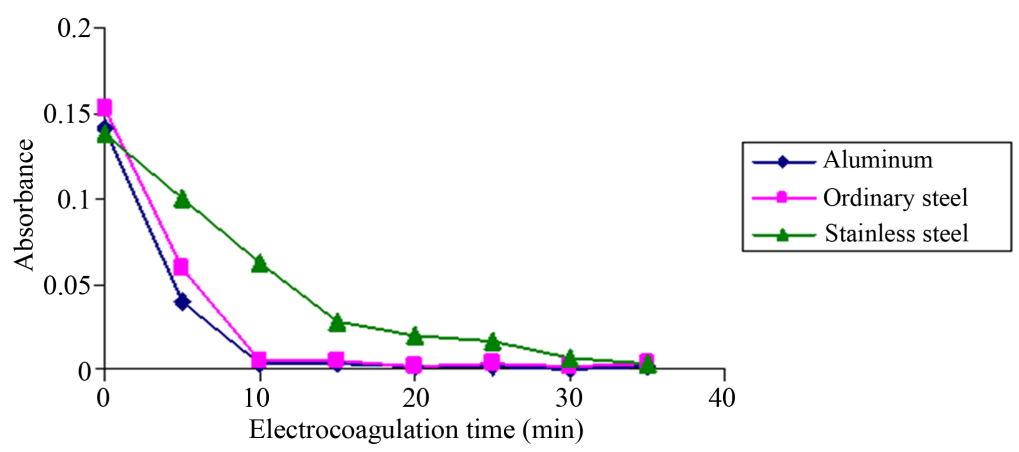

Figure 1. Reduction of cellular concentration of E. coli as a function of electrodes nature during electrocoagulation (ECG) $(I=1 \mathrm{~A})[1]$.

(97.18\%), which is less than aluminum (98.16\%). These results may be explained by the fact that all bacteria are not eliminated or demobilized; a portion of the bacteria may be absorbed on flocs generated during ECG using $\mathrm{Al}$ or Fe electrodes [30] [58].

Jeong et al. [28] studied the action of electrode material on the formation of oxidants, and illustrated the various reaction mechanisms for forming individual oxidants by using boron-doped diamond (BDD), Ti/ $/ \mathrm{RuO}_{2}, \mathrm{Ti} / \mathrm{IrO}_{2}, \mathrm{Ti} / \mathrm{Pt}-\mathrm{IrO}_{2}$, and $\mathrm{Pt}$ as anode materials. The performance of hydroxyl radical $\left({ }^{\circ} \mathrm{OH}\right)$ generation was in the arrangement of $\mathrm{BDD}>>\mathrm{Ti} / \mathrm{RuO}_{2} \approx \mathrm{Pt}$. No crucial formation of ${ }^{\bullet} \mathrm{OH}$ was detected at $\mathrm{Ti} / \mathrm{IrO}_{2}$ and $\mathrm{Ti} / \mathrm{Pt}-\mathrm{IrO}_{2}$. The ${ }^{\bullet} \mathrm{OH}$ was proved to have a fundamental contribution in $\mathrm{O}_{3}$ formation at $\mathrm{BDD}$, but not at the other electrodes. The generation of active $\mathrm{Cl}_{2}$ was in the arrangement of $\mathrm{Ti} / \mathrm{IrO}_{2}>$ $\mathrm{Ti} / \mathrm{RuO}_{2}>\mathrm{Ti} / \mathrm{Pt}-\mathrm{IrO}_{2}>\mathrm{BDD}>\mathrm{Pt}$. The great gap in this arrangement, from that of reactive oxygen species (ROSs), was assigned to the divergence in the electrocatalytic activity of each electrode material with regard to the formation of active $\mathrm{Cl}_{2}$.

Similar results were achieved by López-Gálvez et al. [8]. Table 1 presents the important mechanisms proposed explaining the deadliness of EC technique and their respective cited references.

\section{Electrochemical (EC) Control of Bacterial Persister Cells}

The appearance of antibiotic-resistant bacteria has given an augmenting defiance to infection monitoring [9]. Classical techniques of antibacterial remediation including elevated dose of antibiotics or surgical intervention have been shown inadequate for eliminating constant infections, such as those linked with medical implants. It is well established that bacterial populations frequently hold a low percentage of phenotypic variants, called persister cells, which are metabolically idle and very resistant to antibiotics. When the antibiotic remediation is ceased, remaining alive persister cells may revive the bacterial population with a comparable percentage of persister cells. Therefore, pertinacity gives a hard defiance to curing chronic infections. Niepa [9] presented a new technique for monitoring bacterial pertinacity founded upon a process which was called EC control of 
Table 1. Main mechanisms suggested interpreting the deadliness of EC treatment and their cited references.

\begin{tabular}{|c|c|c|c|}
\hline Oxidants & \multicolumn{3}{|c|}{ Electric field (EF) } \\
\hline $\begin{array}{l}\text { Oxidative stress and } \\
\text { cell loss of life [6] [20] } \\
{[36][43][46][53] .}\end{array}$ & $\begin{array}{c}\text { Irreversible } \\
\text { permeabilization } \\
\text { of cell membranes } \\
\text { [1] [5] [9] [30]. }\end{array}$ & $\begin{array}{c}\text { EO of vital cellular } \\
\text { constituents } \\
{[1][5][47][51] .}\end{array}$ & $\begin{array}{l}\text { Electrosorption of negatively } \\
\text { charged } E \text {. coli cells to the } \\
\text { anode surface + direct electron } \\
\text { transfer reaction } \\
\text { [5] [29] [45] [54]. }\end{array}$ \\
\hline
\end{tabular}

persister cells. This researcher [9] proved that bacterial persister cells could be efficaciously removed by low-level DC; as an example, remediation with 70 $\mu \mathrm{A} / \mathrm{cm}^{2} \mathrm{DC}$ for $1 \mathrm{~h}$ utilizing SS 304 decreased the number of viable planktonic persister cells of $P$. aeruginosa PAO1 by $98 \%$ in comparison with the untreated control [9]. DC applications have an effect on surface charge and membrane integrity of $P$. aeruginosa, conducting to augment intracellular concentration of metal cations [9]. In addition, EC treatments interposed via carbon electrodes induced the permeabilization of the cells to extracellular materials, and elevated their sensibility to antibiotics, which conducted to total elimination of the persisters [59].

\section{Technology Efficiency: Electrochemical (EC) Disinfection vs. Other Methods}

The EC technique was greatly efficient for wastewater remediation [21]. An $E$. coli eliminating performance of $100 \%$ may be obtained for the model water with a residence time of only $0.5 \mathrm{~min}$ and a current density (CD) of $25 \mathrm{~mA} / \mathrm{cm}^{2}$ (Table 2). While the $\mathrm{CD}$ was decreased to $16 \mathrm{~mA} / \mathrm{cm}^{2}$, a residence time of $2 \mathrm{~min}$ was required to give a disinfection performance of $99.98 \%$. EC disinfection was much more performant than classical chlorination. A residence time of at least $30 \mathrm{~min}$ was needed for chlorination to reach a bactericidal performance of $99.94 \%$ or greater. EC disinfection seemed to possess a germicidal performance even bigger than ozonation in terms of residence period. The Fenton reaction was not illustrated as the most efficient disinfection techniques for the model water; however, this was probably formed by the low dosage of Fenton's reagent used in the experimental tests in comparison with the most Fenton reaction conditions.

Diao et al. [21] concluded that all of the disinfection techniques studied in their research (i.e., EC disinfection, chlorination, ozonation and the Fenton reaction), were powerful in eliminating $E$. coli with an initial density of $10^{8} / \mathrm{mL}$ in the examined wastewater. With an eliminating performance of $99.4 \%$ or greater, almost all of the cells in the disinfected samples lost their viability from the viewpoint of being biologically available to incubation (Figure 2).

\section{Electrochemical (EC) Disinfection Mechanisms}

In a general manner, the deactivation of bacteria during disinfection operation 


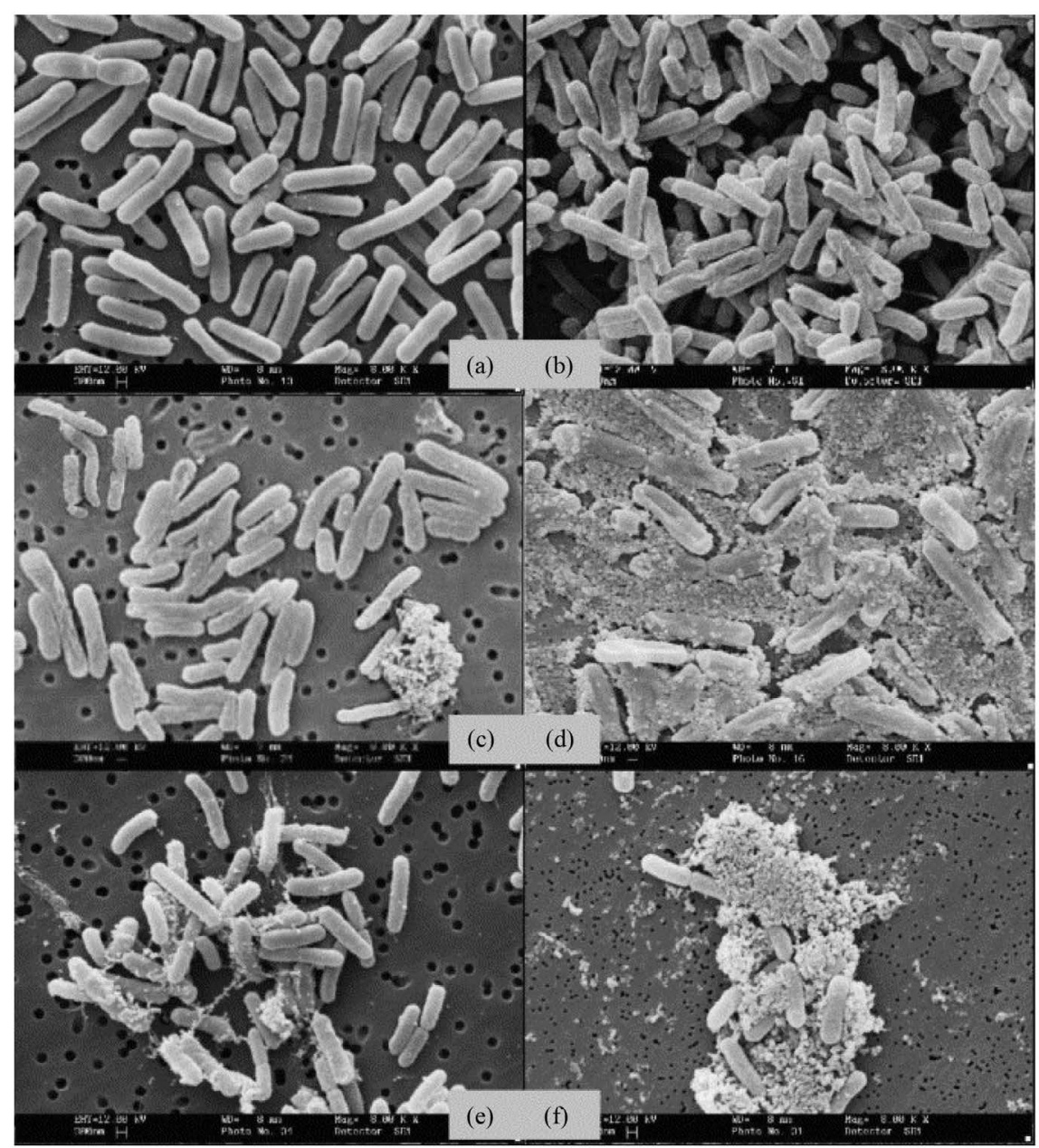

Figure 2. Scanning electron microscopy (SEM) photographs of $E$. coli cells in (a) fresh culture and after (b) chlorination at $5 \mathrm{mg} / \mathrm{L}$ for $30 \mathrm{~min}$; (c) ozonation at $10 \mathrm{mg} / \mathrm{L}$ for 5 min; (d) the Fenton reaction with $8.5 \mathrm{mg} / \mathrm{L} \mathrm{H}_{2} \mathrm{O}_{2}$ and $0.85 \mathrm{mg} / \mathrm{L} \mathrm{Fe}^{2+}$ at $\mathrm{pH} 4$ for $10 \mathrm{~min}$; (e) EC disinfection at $16 \mathrm{~mA} / \mathrm{cm}^{2}$ for $2 \mathrm{~min}$ and (f) $\mathrm{EC}$ disinfection at $25 \mathrm{~mA} / \mathrm{cm}^{2}$ for 2 $\min [21]$.

Table 2. Experimental conditions and bactericidal performances of various disinfection techniques [21].

\begin{tabular}{ccc}
\hline Disinfection method & Testing conditions & Killing efficiency (\%) \\
\hline EC disinfection & $16 \mathrm{~mA} / \mathrm{cm}^{2}, 2 \mathrm{~min}$ & 99.98 \\
& $25 \mathrm{~mA} / \mathrm{cm}^{2}, 0.5 \mathrm{~min}$ & 100 \\
Chlorination & $5 \mathrm{mg} / \mathrm{L}, 30 \mathrm{~min}$ & 99.94 \\
& $5 \mathrm{mg} / \mathrm{L}, 60 \mathrm{~min}$ & 99.98 \\
Ozonation & $10 \mathrm{mg} / \mathrm{L}, 2.5 \mathrm{~min}$ & 99.9 \\
& $10 \mathrm{mg} / \mathrm{L}, 5 \mathrm{~min}$ & 100 \\
Fenton reaction & & 99.4 \\
pH 4, 10 min & $8.5 \mathrm{mg} / \mathrm{L} \mathrm{H}_{2} \mathrm{O}_{2}, 0.85 \mathrm{mg} / \mathrm{L} \mathrm{Fe}^{2+}$ & 99.8 \\
pH 4, 30 min & $8.5 \mathrm{mg} / \mathrm{L} \mathrm{H}_{2} \mathrm{O}_{2}, 0.85 \mathrm{mg} / \mathrm{L} \mathrm{Fe}^{2+}$ & \\
\hline
\end{tabular}


may be usually interpreted by two kinds of destruction to bacterial cells [31]. Primarily, disinfectants may enter in reaction with cell area constituents inducing cell membrane permeability variations or the malfunction of enzymatic diffusion procedures. Secondly, damages to the intracellular constituents, particularly the loss of DNA integrity, may be generated with or without evident cell area destructions [60]. Some disinfectants produce more important deteriorations to either the cell surface area or interior constituents; however, these two kinds of deteriorations are not limited, depending on the $C t$ value (disinfectant dose $\times$ residence time) and kind of bacterial cells. While EC disinfection, the behavior of $E$. coli and Enterococcus is very various, particularly at the start of the process if the concentration of oxidants was less than $2 \mathrm{mg} / \mathrm{L}(0-5 \mathrm{~min}, 4 \mathrm{~V})$ [31]. Comparable findings were observed in the survey on classical chlorination disinfection treatment [61]. The various deactivation kinetics enter the two indicator bacteria are probably linked to their cell surface structure variations (Gram-negative vs. Gram-positive bacteria), because at low $\mathrm{Cl}_{2}$ concentration $\left(<0.5 \mathrm{mg} / \mathrm{L}\right.$, as $\left.\mathrm{Cl}_{2}\right)$, deteriorations of $\mathrm{Cl}_{2}$ were detected importantly to the cell areas [62]. When the $\mathrm{Cl}_{2}$ dose overpass the minimum $\left(1.5 \leq \mathrm{Cl}_{2} \leq 3 \mathrm{mg} / \mathrm{L}\right)$, hard deteriorations to bacterial genomes may appear [62] [63].

Lacasa et al. [64] concluded that the main inactivation mechanisms involve 1) mechanical stress (only for Artemia salina), 2) direct oxidation on the surface of conductive diamond anode, and 3) chemical reactions with chlorine species and/or ROSs ( ${ }^{\circ} \mathrm{OH}, \mathrm{O}_{3}$ or $\mathrm{H}_{2} \mathrm{O}_{2}$ ).

\section{Electrochemical (EC) Disinfection's Free Radicals: Key Contribution in the Killing Actions}

As mentioned previously, the elevated performance of EC disinfection may be given by short-lived and energy rich intermediate products with a more efficient killing capacity [21]. These chemical products obviously comprise free radicals (e.g., ${ }^{\bullet} \mathrm{OH}^{-}$and $\mathrm{O}_{2}{ }^{\bullet}$ ) [17] [65] [66] [67] [68]. By their SEM examination (Figure 2), Diao et al. [21] presented more proof of the hypothesis concerning the important contribution of ${ }^{\bullet} \mathrm{OH}^{-}$in EC disinfection. Cell samples disinfected by ${ }^{-} \mathrm{OH}^{-}$of the Fenton reaction had a rather comparable look as those after EC remediation. There was crucial degeneration and decomposition of the cells following from both the Fenton reaction and EC disinfection. Liberated cellular materials were collected on the filters, which was remarkable to a lesser amplitude for the samples of ozonation and narrowly remarkable for the samples of chlorination. Consequently, in addition to electro-chlorination, $E$. coli cells during EC remediation were probably deactivated by the intermediate products with an oxidizing strength comparable to that of free radicals and much powerful than that of $\mathrm{Cl}_{2}$ [21].

Bio-electro-Fenton devices have been adopted as a cost-efficient and highly efficacious water treatment technique [69]. Zhou et al. [69] studied the demobilization of $E$. coli in a microbial electrolysis cell-based bio-electro-Fenton system 
(microbial electrolytic-Fenton cell). They proved that a 4-log reduction of E. coli ( $10^{7}$ to hundreds CFUs $/ \mathrm{mL}$ ) was attained with an externally applied voltage of $0.2 \mathrm{~V}, 0.3 \mathrm{mM} \mathrm{Fe}^{2+}$, and cathodic $\mathrm{pH}$ of 3.0. Nonetheless, insignificant demobilization was noted in the control tests without external voltage or $\mathrm{Fe}^{2+}$ dose. The killing impact was improved when the cathode airflow rate augmented from 7 to $41 \mathrm{~mL} / \mathrm{min}$ and was also in proportion to the elevation of $\mathrm{Fe}^{2+}$ level from 0.15 to $0.45 \mathrm{mmol} / \mathrm{mL}$. Fatal cell membrane destruction by ${ }^{\bullet} \mathrm{OH}$ was considered as one possible pathway for neutralizing pathogens.

\section{Suggestions for Better Electrochemical (EC) Disinfection}

The real possibilities of the performant disinfection given with the electro-chlorination technique, as an example of EC disinfection, are various. Because disinfection practically may perform with a single pass, the application of the process is very simple in comparison with chemical oxygen demand (COD) elimination, in which recirculation or some type of cascade procedure with several cells has to be utilized. Experience has practically been reached utilizing in-line electro-chlorination for remediation and disinfection of salt water swimming pools, in which the ameliorated disinfection performance from the passing of the cells lets it easy to function at much lower residual $\mathrm{Cl}_{2}$ concentrations $(<0.2 \mathrm{mg} / \mathrm{L})$ that again reduces the concentrations of disinfection by-products (DBPs) [42] [68].

Tanaka et al. [48] suggested an EC disinfection system employing a honeycombed platinum-coated titanium electrode for the disinfection of seawater. Cell suspensions of the fish pathogens, Vibrio alginolyticus, Edwardsiella tarda, Lactococcus garvieae and Vibrio anguillarum were circulated in a reactor provided with 10 sets of these electrodes at a flow rate of $200 \mathrm{~mL} / \mathrm{min}$ with an applied potential of $1.0 \mathrm{~V}$ vs. $\mathrm{Ag} / \mathrm{AgCl}$ reference electrode. The circulated cells were totally killed after $3 \mathrm{~h}$ of treatment, whereas free residual $\mathrm{Cl}_{2}$ generated due to seawater electrolysis was below $0.1 \mathrm{mg} / \mathrm{L}$. Moreover, a diphenyl-1-pyrenylphosphine fluorescent assay showed that lipid peroxidation in the cell membranes of disinfected bacteria was induced probably by ROSs produced in the course of EC application.

Hashim et al. [70] suggested a novel combined ultrasonic-electrocoagulation device (U-ECG setup) to kill $E$. coli in water. The U-ECG reactor is composed of an ultrasonic bath fitted with four perforated $\mathrm{Al}$ electrodes, which are designed to serve as baffle-plates to improve the water-mixing phenomenon. The novel U-ECG device neutralized $100 \%$ of the E. coli during $11 \mathrm{~min}$ of application instead of 23 min for ECG.

Cotillas et al. [71] worked on merging iron ECG (Fe-ECG) and UV irradiation (photo-ECG) for eliminating turbidity and E. coli from real treated municipal wastewaters. Sole Fe-ECG was found very performant even at low CDs. E. coli is retained not only via the enmeshment of mechanism into flocs [72] [73], but also via the attack of electrochemically formed chlorine disinfectant species. Inte- 
grating UV irradiation with Fe-ECG ameliorates the technology effectiveness in dealing with $E$. coli and turbidity. There is a synergistic interaction of both methods at low CD $\left(1.44 \mathrm{~A} / \mathrm{m}^{2}\right)$ but an antagonistic impact at higher levels of $\mathrm{CD}$ $\left(7.20 \mathrm{~A} / \mathrm{m}^{2}\right)$. Such an antagonistic impact is provoked by the less efficacious transmission of UV irradiation to the bulk solution due to the elevation in the level of colloids.

Rodríguez-Chueca et al. [74] implemented the Fenton-like techniques induced via radiofrequency for neutralizing fecal bacteria (E. coli and Enterococcus sp.) existing in treated domestic wastewater effluents. Fenton techniques were performed at $\mathrm{pH} 5$ with various iron sources, like iron salts (ferric chloride, 5, 50 and $\left.100 \mathrm{mg} / \mathrm{L} \mathrm{Fe}^{3+}\right)$, magnetite $(1 \mathrm{~g} / \mathrm{L})$ and clay $(80 \mathrm{~g} / \mathrm{L}), \mathrm{H}_{2} \mathrm{O}_{2}(25 \mathrm{mg} / \mathrm{L})$ and in absence and presence of radiofrequency. Two distinct electromagnetic field intensities $(1.57$ and $3.68 \mathrm{kA} / \mathrm{m})$ were employed in the Fenton techniques induced by radiofrequency. Ferromagnetic material/ $\mathrm{H}_{2} \mathrm{O}_{2} /$ radiofrequency techniques attained interesting findings in killing bacterial cells. For example, $\mathrm{Fe}^{3+} / \mathrm{H}_{2} \mathrm{O}_{2}$ /radiofrequency attained a maximum degree of $E$. coli demobilization of $3.55 \mathrm{log}$ following $10 \mathrm{~min}$ of application. Such performances are bigger than those recorded in the absence of radiofrequency are. Activating thermally iron atoms lets the Fenton reaction to intensifying, improving the final efficiency of the technique. In addition, distinct behavior was noted in killing E. coli and Enterococcus sp. due to the structural differences between Gram-negative and Gram-positive bacteria [74] [75].

Heffron et al. [76] suggested the removal of viruses by utilizing ECG as a pretreatment prior to EO treatment using BDD electrodes. They employed bench-scale and batch setups to assess the alleviation of viruses via EO and a sequential ECG-EO treatment train. They found that EO of two bacteriophages (MS2 and FX174) was restrained by NOM and turbidity, showing the possible demand for pretreatment. Nonetheless, the ECG-EO treatment train was useful only in the model surface waters tested. In model groundwater, ECG single was as performant as the merged ECG-EO treatment train. Neutralizing human echovirus was considerably smaller than one or both bacteriophages in all model waters; nevertheless, bacteriophage FX174 was a more representative surrogate than MS2 in the occurrence of NOM and turbidity. Juxtaposed to traditional treatment by ferric salt coagulant and free chlorine disinfection, the ECG-EO reactor was less efficient in model surface waters but more performant in model groundwater. Successive ECG-EO was helpful for many implementations, even if engineering factors could presently outbalance the merits.

Bruguera-Casamada et al. [77] worked on the disinfection of raw dairy wastewater by using a successive treatment involving an ECG stage with a Fe-Fe reactor pursued by electro-Fenton or ultraviolet (UV) A (315 nm - $400 \mathrm{~nm}$ ) [78] [79] (UVA)-assisted photo-electro-Fenton. The two latter techniques were performed with an air-diffusion cathode for $\mathrm{H}_{2} \mathrm{O}_{2}$ formation and either a BDD or a $\mathrm{RuO}_{2}$-based anode. They examined the demobilization of heterotrophic and lactic acid bacteria, E. coli and enterococci. A modest reduction of the organic load 
was observed in all circumstances, while the microbes were deficiently retained by the flocs produced in ECG but considerably demobilized in electro-Fenton and photo-electro-Fenton. Compared to ECG, electro-Fenton was of value as it avoided the generation of toxic sludge carrying active bacteria. In the consecutive ECG/electro-Fenton method implying a BDD anode in the latter stage, the killing yield for the lactic acid bacteria was more important at neutral $\mathrm{pH}$, thanks to the large capacity of formed $\mathrm{Cl}_{2}$ to oxidize the molecules of the cell walls. Moreover, employing a $\mathrm{RuO}_{2}$-based anode conducted to a rapid neutralization at $\mathrm{pH}$ 3.0. A better achievement was recorded if photo-electro-Fenton substituted electro-Fenton, regardless of the anode, thanks to the improved bacterial demobilization by UVA radiation.

Anodic ECG techniques could eliminate large sets of contaminants in industrial wastewater even if some stubborn pollutants can stay in effluents following the treatment and provoke environmental problems. To elevate the performance of eliminating contaminants, Fan et al. [80] combined electrocatalysis with ECG and implemented an atomic layer deposition (ALD) that enabled $\mathrm{TiO}_{2}$ ultrathin overcoating at a nanometer scale on a stainless steel cathode. The electrocatalytic overcoating augmented the reduction performance of organic compounds and microbes, mainly thanks to the electro-formation of appropriate ROSs. By employing the new ECG-electrocatalysis reactor to deal with synthetic wastewater, interesting reductions of $99.92 \%$ of $E$. coli, $92.1 \%$ of suspended solids, $98.3 \%$ of heavy metal ions, and $88.8 \%$ of methylene blue were noted. Such an integrated EC technology could lead to treating wastewater at an industrial scale.

\section{Disinfection By-Products (DBPs) Formation: An Electrochemical (EC) Disinfection Undesirable Side Effect}

As mentioned in the previous Section, chemical water treatment issues such as DBPs formation have incited on the search of better water treatment means such as EC water processes that have been tested with large success in various water/wastewater pollutant treatments [81]. However, their large use is blocked by many technical issues such as DBPs especially chlorine by-products (CBPs) produced species [7] [82]. In fact, in the course of EC treatment, these carcinogenic products may be generated following the electrode material and applied voltage. In our previous review paper [3], we have discussed the dependence of CBPs produced species generation of the electrode material and applied charge in the course of EC treatment. It was deduced that the usage of electrodes generating highly reactive species has to be more cautiously monitored in hygienically and environmentally oriented using. Following this orientation, Pt and BDD anodes are proved more appropriate than other electrodes. In fact, the good capacity of a BDD anode to generate ROSs and other oxidizing species during the electrolysis allows establishing a chlorine-free disinfection process [83].

ECG could be incorporated ahead of microfiltration (MF) to efficiently remove turbidity, microbes, and DBPs and together keep an elevated MF specific flux [84]. Indeed, ECG efficaciously eliminates hydrophobic natural organic 
matter (NOM) and pathogens. As seen above, ECG effectively removes viruses via physically encapsulating them in flocs, neutralizing their surface charge and decreasing electrostatic repulsion, and enhancing hydrophobic interactions between any sorbed NOM and free viruses [85]. Chellam and Sari [84] concluded that ECG attains DBP control via reducing NOM, decreasing chlorine-reactivity of the residual NOM.

Bergmann and Koparal [7] concluded that practical setups must be conceived and monitored in a sophisticated manner. The actual state of non-monitored use of disinfection devices is not favorable in terms of hygienic and health risks considerations. Great works remain to be performed.

Employing mixed metal oxide anodes has been proved for disinfecting water with reduced formation of CBPs. However, more attention is required to improve the technology [86]. Table 3 lists the dares encountered in the water treatment industry related to EC disinfection [82].

$\mathrm{Xu}$ et al. [92] studied the ECG of landfill leachate during which the formation of chlorine species could lead to the production of toxic DBPs. They investigated such a generation via observing five categories of DBPs (haloacetic acids-HAAs, THMs, haloacetonitriles-HANs, haloketones-HKs, and halonitromethanes-HNMs) in two leachate samples treated by ECG. It was illustrated that the applied current has induced the production of DBPs that were prevailed by unregulated DBPs. With a CD of $100 \mathrm{~mA} / \mathrm{cm}^{2}$, the unregulated $\mathrm{HKs}$ prevailed the weight-based DBP level (96\% in Leachate A and $44.3 \%$ in Leachate B), while the unregulated HANs took part in $>80 \%$ of the DBPs additive toxicity in both leachates. The in

Table 3. Dares in the water treatment industry related to EC disinfection [82].

\begin{tabular}{|c|c|}
\hline Challenge & Description \\
\hline Challenge \# 1 & $\begin{array}{l}\text { The first dare is how to avert the generation of poisonous by-products like } \\
\text { chlorates or trihalomethanes (THMs). Chlorates are produced via oxidation } \\
\text { of hypochlorite or via its disproportionation that is a natural phenomenon } \\
\text { that also happens during the aging of the disinfected water. Chlorates provoke } \\
\text { grave health issues because as they touch the nervous system. The second kind } \\
\text { of poisonous species is even more polemic. Indeed, chlorinated chemicals } \\
\text { are produced from the integration of organic matter with active species of } \\
\text { chlorine, and such products are linked to cancer and many so grave diseases. } \\
\text { Such compounds are not limited to the EC technology since they are } \\
\text { were related to classical chlorination implementation. }\end{array}$ \\
\hline Challenge \#2 & $\begin{array}{l}\text { The second dare is to utilize substitutes for mixed metal oxide anodes, } \\
\text { like diamond-like coatings, having the ability of not only oxidizing chloride } \\
\text { ions but also forming more efficacious agents, comprising }{ }^{\bullet} \mathrm{OH} \text {. If employing } \\
\text { such electrodes, issues related to the generation of toxic species could worsen, } \\
\text { due to the well-established formation of perchlorates through chlorates } \\
\text { oxidation. Such novel electrode materials could improve the work of } \\
\text { additional oxidizing reagents (like ozone and peroxosalts [78] [87] [88]) } \\
\text { to aid in dealing with resistant pathogens [89] [90]. Issues could be resolved } \\
\text { via following some procedures such as more optimized residence period } \\
\text { among water and the anodes in the electrolyzer, and a sufficiently big specific } \\
\text { current and the cathodic generation of } \mathrm{H}_{2} \mathrm{O}_{2} \text { to avoid more oxidation } \\
\text { of chlorine to chlorates and perchlorates [91]. }\end{array}$ \\
\hline
\end{tabular}


situ formations of active chlorine has conducted to the DBP production, as illustrated in the scavenging test. Using granular activated carbon as a post-treatment stage can successfully decrease the total DBP level from 295.33 to $82.04 \mu \mathrm{g} / \mathrm{L}$ in Leachate A, conducting to a global DBP reduction of $72.2 \%$ and a toxicity decrease of $50 \%$. Considering the controlling level and shortage of toxicity data, the unregulated DBPs have to retain more interest [93] [94] [95].

\section{Conclusions}

The main important points drawn from this review may be drawn as:

1) Some mechanisms have been suggested to interpret the deadliness of EC application [96]. Such pathways comprise 1) oxidative stress and cell loss of life because of electrochemically produced oxidants, 2) irreversible permeabilization of cell membranes by the placed EF, 3) EO of vital cellular constituents during exposure to electric current or induced EFs, and 4) electrosorption of negatively charged $E$. coli cells to the anode surface followed by direct electron transfer reaction [97] [98] [99]. Physical elimination via enmeshment in ECG flocs is the main mechanism of bacteria reduction in the occurrence of $\mathrm{HCO}_{3}^{-}$, which greatly reduces demobilization, probably due to a decrease in the lifetime of reactive oxidants [100]. Adhesion of ECG flocs to cell walls, which conducts to microbes' encapsulation in flocs, is mainly directed by interactions among ECG flocs and phosphate functional groups on bacteria surfaces. ECG flocs' fixation is a function of the cell wall composition, consistent with comparable densities of phosphate functional groups on Gram-positive and Gram-negative cells [101] [102] [103].

2) EFs are by their nature poisonous to microbial cells. Future investigations have to be more dedicated to the EF influence in the EC disinfection, as it is the main part of the involved mechanisms.

3) Employing granular activated carbon post-treatment could greatly reduce the concentrations and poisonous effects of DBPs. Moreover, secure multi-barrier techniques, like distillation (solar disinfection) [104] [105], plasma discharge [106], nanotechnologies [107], and membrane processes [108] [109] remain to be suggested, tested, and industrially encouraged. Despite their limitations, both adsorptive techniques and membrane processes persist to be an encouraging domain of research thanks to their relatively low costs and ease of applications [110] [111] [112].

\section{Acknowledgements}

The Research Deanship of University of Ha'il, Saudi Arabia, through the Project RG-191190, has funded this research.

\section{Conflicts of Interest}

The author declares no conflicts of interest regarding the publication of this paper. 


\section{References}

[1] Ghernaout, D., Badis, A., Kellil, A. and Ghernaout, B. (2008) Application of Electrocoagulation in Escherichia coli Culture and Two Surface Waters. Desalination, 219, 118-125. https://doi.org/10.1016/j.desal.2007.05.010

[2] Ghernaout, D. and Ghernaout, B. (2010) From Chemical Disinfection to Electrodisinfection: The Obligatory Itinerary? Desalination and Water Treatment, 16, 156-175. https://doi.org/10.5004/dwt.2010.1085

[3] Ghernaout, D., Naceur, M.W. and Aouabed, A. (2011) On the Dependence of Chlorine by Products Generated Species Formation of the Electrode Material and Applied Charge during Electrochemical Water Treatment. Desalination, 270, 9-22. https://doi.org/10.1016/j.desal.2011.01.010

[4] Ghernaout, D. and Naceur, M.W. (2011) Ferrate(VI): In Situ Generation and Water Treatment-A Review. Desalination and Water Treatment, 30, 319-332. https://doi.org/10.5004/dwt.2011.2217

[5] Feng, C., Suzuki, K., Zhao, S., Sugiura, N., Shimada, S. and Maekawa, T. (2004) Water Disinfection by Electrochemical Treatment. Bioresource Technology, 94, 21-25. https://doi.org/10.1016/j.biortech.2003.11.021

[6] Drees, K.P., Abbaszadegan, M. and Maier, R.M. (2003) Comparative Electrochemical Inactivation of Bacteria and Bacteriophage. Water Research, 37, 2291-2300. https://doi.org/10.1016/S0043-1354(03)00009-5

[7] Bergmann, H. and Koparal, S. (2005) The Formation of Chlorine Dioxide in the Electrochemical Treatment of Drinking Water for Disinfection. Electrochimica Acta, 50, 5218-5228. https://doi.org/10.1016/j.electacta.2005.01.061

[8] López-Gálvez, F., Posada-Izquierdo, G.D., Selma, M.V., Pérez-Rodríguez, F., Gobet, J., Gil, M.I. and Allende, A. (2012) Electrochemical Disinfection: An Efficient Treatment to Inactivate Escherichia coli O157:H7 in Process Wash Water Containing Organic Matter. Food Microbiology, 30, 146-156. https://doi.org/10.1016/j.fm.2011.09.010

[9] Niepa, T.H.R. (2014) Electrochemical Control of Bacterial Persister Cells. PhD Thesis, Syracuse University, Syracuse, NY.

[10] Cahen Jr., G.L. (1976) Electrochemical Disinfection: A Fundamental Study. PhD Thesis, University of Virginia, Charlottesville, VA.

[11] Ghernaout, D. (2013) Advanced Oxidation Phenomena in Electrocoagulation Process: A Myth or a Reality? Desalination and Water Treatment, 51, 7536-7554. https://doi.org/10.1080/19443994.2013.792520

[12] Davis, C.P., Shirtliff, M.E., Trieff, N.M., Hoskins, S.L. and Warren, M.M. (1994) Quantification, Qualification, and Microbial Killing Efficiencies of Antimicrobial Chlorine-Based Substances Produced by Iontophoresis. Antimicrobial Agents and Chemotherapy, 38, 2768-2774. https://doi.org/10.1128/AAC.38.12.2768

[13] Gaskova, D., Sigler, K., Janderova, B. and Plasek, J. (1996) Effect of High-Voltage Electric Pulses on Yeast Cells: Factors Influencing the Killing Efficiency. Bioelectrochemistry and Bioenergetics, 39, 195-202. https://doi.org/10.1016/0302-4598(95)01892-1

[14] Grahl, T. and Markl, H. (1996) Killing of Microorganisms by Pulsed Electric Fields. Applied Microbiology and Biotechnology, 45, 148-157. https://doi.org/10.1007/s002530050663

[15] Matsunaga, T., Namba, Y. and Nakajima, T. (1984) 751-Electrochemical Sterilization of Microbial Cells. Bioelectrochemistry and Bioenergetics, 13, 393-400. 
https://doi.org/10.1016/0302-4598(84)87040-3

[16] Matsunaga, T., Naksono, S., Takamuku, T., Burgess, J.G., Nakamura, N. and Sode, K. (1992) Disinfection of Drinking Water by Using a Novel Electrochemical Reactor Employing Carbon-Cloth Electrodes. Applied and Environmental Microbiology, 58, 686-689. https://doi.org/10.1128/AEM.58.2.686-689.1992

[17] Patermarakis, G. and Fountoukidis, E. (1990) Disinfection of Water by Electrochemical Treatment. Water Research, 24, 1491-1496. https://doi.org/10.1016/0043-1354(90)90083-I

[18] Tokuda, H. and Nakanishi, K. (1995) Application of Direct Current to Protect Bioreactor against Contamination. Bioscience, Biotechnology, and Biochemistry, 59, 753-755. https://doi.org/10.1271/bbb.59.753

[19] Velizarov, S. (1999) Electric and Magnetic Fields in Microbial Biotechnology: Possibilities, Limitations, and Perspectives. Electro- and Magnetobiology, 18, 185-212. https://doi.org/10.3109/15368379909012912

[20] Kerwick, M.I., Reddy, S.M., Chamberlain, A.H.L. and Holt, D.M. (2005) Electrochemical Disinfection, an Environmentally Acceptable Method of Drinking Water Disinfection? Electrochimica Acta, 50, 5270-5277. https://doi.org/10.1016/j.electacta.2005.02.074

[21] Diao, H.F., Li, X.Y., Gu, J.D., Shi, H.C. and Xie, Z.M. (2004) Electron Microscopic Investigation of the Bactericidal Action of Electrochemical Disinfection in Comparison with Chlorination, Ozonation and Fenton Reaction. Process Biochemistry, 39, 1421-1426. https://doi.org/10.1016/S0032-9592(03)00274-7

[22] Dewil, R., Mantzavinos, D., Poulios, I. and Rodrigo, M.A. (2017) New Perspectives for Advanced Oxidation Processes. Journal of Environmental Management, 195, 93-99. https://doi.org/10.1016/j.jenvman.2017.04.010

[23] Särkkä, H., Bhatnagar, A. and Sillanpää, M. (2015) Recent Developments of Electro-Oxidation in Water Treatment-A Review. Journal of Electroanalytical Chemistry, 754, 46-56. https://doi.org/10.1016/j.jelechem.2015.06.016

[24] Zheng, T., Wang, J., Wang, Q., Meng, H. and Wang, L. (2017) Research Trends in Electrochemical Technology for Water and Wastewater Treatment. Applied Water Science, 7, 13-30. https://doi.org/10.1007/s13201-015-0280-4

[25] Cotillas, S., Llanos, J., Cañizares, P., Mateo, S. and Rodrigo, M.A. (2013) Optimization of an Integrated Electrodisinfection/Electrocoagulation Process with Al Bipolar Electrodes for Urban Wastewater Reclamation. Water Research, 47, 1741-1750. https://doi.org/10.1016/j.watres.2012.12.029

[26] Delaedt, Y., Daneels, A., Declerck, P., Behets, J., Ryckeboer, J., Peters, E. and Ollevier, F. (2008) The Impact of Electrochemical Disinfection on Escherichia coli and Legionella pneumophila in Tap Water. Microbiological Research, 163, 192-199. https://doi.org/10.1016/j.micres.2006.05.002

[27] Liu, W.K., Brown, M.R.W. and Elliot, T.S.J. (1997) Mechanisms of the Bactericidal Activity of Low Amperage Electric Current (DC). Journal of Antimicrobial Chemotherapy, 39, 687-695. https://doi.org/10.1093/jac/39.6.687

[28] Jeong, J., Kim, C. and Yoon, J. (2009) The Effect of Electrode Material on the Generation of Oxidants and Microbial Inactivation in the Electrochemical Disinfection Processes. Water Research, 43, 895-901. https://doi.org/10.1016/j.watres.2008.11.033

[29] Jeong, J., Kim, J.Y., Cho, M., Choi, W. and Yoon, J. (2007) Inactivation of Escherichia coli in the Electrochemical Disinfection Process Using a Pt Anode. Chemosphere, 67, 652-659. https://doi.org/10.1016/j.chemosphere.2006.11.035 
[30] Hakizimana, J.N., Gourich, B., Vial, Ch., Drogui, P., Oumani, A., Naja, J. and Hilali, L. (2016) Assessment of Hardness, Microorganism and Organic Matter Removal from Seawater by Electrocoagulation as a Pretreatment of Desalination by Reverse Osmosis. Desalination, 393, 90-101. https://doi.org/10.1016/j.desal.2015.12.025

[31] Huang, X., Qu, Y., Cid, C.A., Finke, C., Hoffmann, M.R., Lim, K. and Jiang, S.C. (2016) Electrochemical Disinfection of Toilet Wastewater Using Wastewater Electrolysis Cell. Water Research, 92, 164-172. https://doi.org/10.1016/j.watres.2016.01.040

[32] Venczel, L.V., Arrowood, M., Hurd, M. and Sobsey, M.D. (1997) Inactivation of Cryptosporidium parvum Oocysts and Clostridium perfringens Spores by a Mixed-Oxidant Disinfectant and by Free Chlorine. Applied and Environmental Microbiology, 63, 1598-1601. https://doi.org/10.1128/AEM.63.4.1598-1601.1997

[33] Costerton, J.W., Ellis, B., Lam, K., Johnson, F. and Khoury, A.E. (1994) Mechanism of Electrical Enhancement of Efficacy of Antibiotics in Killing Biofilm Bacteria. Antimicrobial Agents and Chemotherapy, 38, 2803-2809.

https://doi.org/10.1128/AAC.38.12.2803

[34] Khoury, A.E., Lam, K., Ellis, B. and Costerton, J.W. (1992) Prevention and Control of Bacterial Infections Associated with Medical Devices. ASAIO Journal, 38, M174-M178.

[35] Mascia, M., Vacca, A. and Palmas, S. (2012) Fixed Bed Reactors with Three Dimensional Electrodes for Electrochemical Treatment of Waters for Disinfection. Chemical Engineering Journal, 211-212, 479-487. https://doi.org/10.1016/j.cej.2012.09.091

[36] Mascia, M., Vacca, A. and Palmas, S. (2013) Electrochemical Treatment as a Pre-Oxidative Step for Algae Removal Using Chlorella vulgaris as a Model Organism and BDD Anodes. Chemical Engineering Journal, 219, 512-519. https://doi.org/10.1016/j.cej.2012.12.097

[37] Cui, X., Quicksall, A.N., Blake, A.B. and Talley, J.W. (2013) Electrochemical Disinfection of Escherichia coli in the Presence and Absence of Primary Sludge Particulates. Water Research, 47, 4383-4390. https://doi.org/10.1016/j.watres.2013.04.039

[38] Nanayakkara, K.G.N., Alam, A.K.M.K., Zheng, Y.-M. and Chen, J.P. (2012) A low-Energy Intensive Electrochemical System for the Eradication of Escherichia coli from Ballast Water: Process Development, Disinfection Chemistry, and Kinetics Modeling. Marine Pollution Bulletin, 64, 1238-1245.

https://doi.org/10.1016/j.marpolbul.2012.01.018

[39] Weaver, J.C. and Chizmadzhev, Y.A. (1996) Theory of Electroporation: A Review. Bioelectrochemistry and Bioenergetics, 41, 135-160. https://doi.org/10.1016/S0302-4598(96)05062-3

[40] Rajab, M., Heim, C., Letzel, T., Drewes, J.E. and Helmreich, B. (2015) Electrochemical Disinfection Using Boron-Doped Diamond Electrode-The Synergetic Effects of in Situ Ozone and Free Chlorine Generation. Chemosphere, 121, 47-53. https://doi.org/10.1016/j.chemosphere.2014.10.075

[41] Kraft, A. (2008) Electrochemical Water Disinfection: A Short Review. Platinum Metals Review, 52, 177-185. https://doi.org/10.1595/147106708X329273

[42] Muff, J. (2014) Chap. 3. Electrochemical Oxidation-A Versatile Technique for Aqueous Organic Contaminant Degradation. In: Søgaard, E.G., Ed., Chemistry of Advanced Environmental Purification Processes of Water, Elsevier B.V., Amsterdam, 75-134. https://doi.org/10.1016/B978-0-444-53178-0.00003-1

[43] Li, H., Zhu, X. and Ni, J. (2011) Comparison of Electrochemical Method with Ozonation, Chlorination and Monochloramination in Drinking Water Disinfection. 
Electrochimica Acta, 56, 9789-9796. https://doi.org/10.1016/j.electacta.2011.08.053

[44] Farooqui, M.S. (2004) Combined Electrooxidation and Electrocoagulation Processes for the Treatment of Municipal Wastewater. Master of Science Thesis, King Fahd University of Petroleum \& Minerals, Dhahran.

[45] Hussain, S.N., Trzcinski, A.P., Asghar, H.M.A., Sattar, H., Brown, N.W. and Roberts, E.P.L. (2016) Disinfection Performance of Adsorption Using Graphite Adsorbent Coupled with Electrochemical Regeneration for Various Microorganisms Present in Water. Journal of Industrial and Engineering Chemistry, 44, 216-225. https://doi.org/10.1016/j.jiec.2016.09.009

[46] Okochi, M., Nakamura, N. and Matsunaga, T. (1999) Electrochemical Killing of Microorganisms Using the Oxidized Form of Ferrocenemonocarboxylic Acid. Electrochimica Acta, 44, 3795-3799. https://doi.org/10.1016/S0013-4686(99)00085-7

[47] Okochi, M., Nakamura, N. and Matsunaga, T. (2000) Electrochemical Killing of Vibrio alginolyticus Using Ferrocene-Modified Electrode. Electrochimica Acta, 45, 2917-2921. https://doi.org/10.1016/S0013-4686(00)00368-6

[48] Tanaka, T., Shimoda, M., Shionoiri, N., Hosokawa, M., Taguchi, T., Wake, H. and Matsunaga, T. (2013) Electrochemical Disinfection of Fish Pathogens in Seawater without the Production of a Lethal Concentration of Chlorine Using a Flow Reactor. Journal of Bioscience and Bioengineering, 116, 480-484. https://doi.org/10.1016/j.jbiosc.2013.04.013

[49] Talaiekhozani, A., Talaei, M.R. and Rezania, S. (2017) An Overview on Production and Application of Ferrate (VI) for Chemical Oxidation, Coagulation and Disinfection of Water and Wastewater. Journal of Environmental Chemical Engineering, 5, 1828-1842. https://doi.org/10.1016/j.jece.2017.03.025

[50] Cano, A., Barrera, C., Cotillas, S., Llanos, J., Cañizares, P. and Rodrigo, M.A. (2016) Use of DiaCell Modules for the Electro-Disinfection of Secondary-Treated Wastewater with Diamond Anodes. Chemical Engineering Journal, 306, 433-440. https://doi.org/10.1016/j.cej.2016.07.090

[51] Bergmann, H., Koparal, A.T., Koparal, A.S. and Ehrig, F. (2008) The Influence of Products and By-Products Obtained by Drinking Water Electrolysis on Microorganisms. Microchemical Journal, 89, 98-107. https://doi.org/10.1016/j.microc.2007.12.007

[52] Henquín, E.R., Colli, A.N., Bergmann, M.E.H. and Bisang, J.M. (2013) Characterization of a Bipolar Parallel-Plate Electrochemical Reactor for Water Disinfection Using Low Conductivity Drinking Water. Chemical Engineering and Processing: Process Intensification, 65, 45-52. https://doi.org/10.1016/j.cep.2012.12.007

[53] Polcaro, A.M., Vacca, A., Mascia, M., Palmas, S., Pompei, R. and Laconi, S. (2007) Characterization of a Stirred Tank Electrochemical Cell for Water Disinfection Processes. Electrochimica Acta, 52, 2595-2602. https://doi.org/10.1016/j.electacta.2006.09.015

[54] Llanos, J., Cotillas, S., Cañizares, P. and Rodrigo, M.A. (2015) Conductive Diamond Sono Electrochemical Disinfection (CDSED) for Municipal Wastewater Reclamation. Ultrasonics Sonochemistry, 22, 493-498. https://doi.org/10.1016/j.ultsonch.2014.05.009

[55] Llanos, J., Cotillas, S., Cañizares, P. and Rodrigo, M.A. (2014) Effect of Bipolar Electrode Material on the Reclamation of Urban Wastewater by an Integrated Electrodisinfection/Electrocoagulation Process. Water Research, 53, 329-338. https://doi.org/10.1016/j.watres.2014.01.041

[56] Zhang, R. (2010) Study of the Influence of Reactor Design and Process Parameters 
on Electrochemical Disinfection in Wastewater. Master of Science Thesis, Lamar University, Beaumont, TX.

[57] Schmalz, V., Dittmar, T., Haaken, D. and Worch, E. (2009) Electrochemical Disinfection of Biologically Treated Wastewater from Small Treatment Systems by Using Boron-Doped Diamond (BDD) Electrodes-Contribution for Direct Reuse of Domestic Wastewater. Water Research, 43, 5260-5266.

https://doi.org/10.1016/j.watres.2009.08.036

[58] Boudjema, N., Drouiche, N., Abdi, N., Grib, H., Lounici, H., Pauss, A. and Mameri, N. (2014) Treatment of Oued El Harrach River Water by Electrocoagulation Noting the Effect of the Electric Field on Microorganisms. Journal of the Taiwan Institute of Chemical Engineers, 45, 1564-1570. https://doi.org/10.1016/j.jtice.2013.10.006

[59] Niepa, T.H.R., Gilbert, J.L. and Ren, D. (2012) Controlling Pseudomonas aeruginosa Persister Cells by Weak Electrochemical Currents and Synergistic Effects with Tobramycin. Biomaterials, 33, 7356-7365. https://doi.org/10.1016/j.biomaterials.2012.06.092

[60] Cho, M., Kim, J., Kim, J.Y., Yoon, J. and Kim, J.-H. (2010) Mechanisms of Escherichia coli Inactivation by Several Disinfectants. Water Research, 44, 3410-3418. https://doi.org/10.1016/j.watres.2010.03.017

[61] Tree, J.A., Adams, M.R. and Lees, D.N. (2003) Chlorination of Indicator Bacteria and Viruses in Primary Sewage Effluent. Applied and Environmental Microbiology, 69, 2038-2043. https://doi.org/10.1128/AEM.69.4.2038-2043.2003

[62] Phe, M.-H., Dossot, M., Guilloteau, H. and Block, J.-C. (2005) Nucleic Acid Fluorochromes and Flow Cytometry Prove Useful in Assessing the Effect of Chlorination on Drinking Water Bacteria. Water Research, 39, 3618-3628. https://doi.org/10.1016/j.watres.2005.06.002

[63] Ramseier, M.K., von Gunten, U., Freihofer, P. and Hammes, F. (2011) Kinetics of Membrane Damage to High (HNA) and Low (LNA) Nucleic Acid Bacterial Clusters in Drinking Water by Ozone, Chlorine, Chlorine Dioxide, Monochloramine, Ferrate(VI), and Permanganate. Water Research, 45, 1490-1500. https://doi.org/10.1016/j.watres.2010.11.016

[64] Lacasa, E., Tsolaki, E., Sbokou, Z., Rodrigo, M.A., Mantzavinos, D. and Diamadopoulos, E. (2013) Electrochemical Disinfection of Simulated Ballast Water on Conductive Diamond Electrodes. Chemical Engineering Journal, 223, 516-523. https://doi.org/10.1016/j.cej.2013.03.003

[65] Li, X.Y., Ding, F., Lo, P.S.Y. and Sin, S.H.P. (2002) Electrochemical Disinfection of Saline Wastewater Effluent. Journal of Environmental Engineering, 128, 697-704. https://doi.org/10.1061/(ASCE)0733-9372(2002)128:8(697)

[66] Johnson, S.K., Houk, L.L., Feng, J.R., Houk, R.S. and Johnson, D.C. (1999) Electrochemical Incineration of 4-Chlorophenol and Identification of Products and Intermediates by Mass Spectrometry. Environmental Science \& Technology, 33, 2638-2644. https://doi.org/10.1021/es981045r

[67] Oturan, M.A. (2000) An Ecologically Effective Water Treatment Technique Using Electrochemically Generated Hydroxyl Radicals for in Situ Destruction of Organic Pollutants: Application to Herbicide 2,4-D. Journal of Applied Electrochemistry, 30, 475-482. https://doi.org/10.1023/A:1003994428571

[68] Schaefer, C.E., Andaya, C. and Urtiaga, A. (2015) Assessment of Disinfection and By-Product Formation during Electrochemical Treatment of Surface Water Using a $\mathrm{Ti} / \mathrm{IrO}_{2}$ Anode. Chemical Engineering Journal, 264, 411-416. https://doi.org/10.1016/j.cej.2014.11.082 
[69] Zhou, S., Huang, S., Li, X., Angelidaki, I. and Zhang, Y. (2018) Microbial Electrolytic Disinfection Process for Highly Efficient Escherichia coli Inactivation. Chemical Engineering Journal, 342, 220-227. https://doi.org/10.1016/j.cej.2018.02.090

[70] Hashim, K.S., Ali, S.S.M., AlRifaie, J.K., Kot, P., Shaw, A., Al Khaddar, R., Idowu, I. and Gkantou, M. (2020) Escherichia coli Inactivation Using a Hybrid Ultrasonic-Electrocoagulation Reactor. Chemosphere, 247, Article ID: 125868.

https://doi.org/10.1016/j.chemosphere.2020.125868

[71] Cotillas, S., Llanos, J., Miranda, O.G., Díaz-Trujillo, G.C., Cañizares, P. and Rodrigo, M.A. (2014) Coupling UV Irradiation and Electrocoagulation for Reclamation of Urban Wastewater. Electrochimica Acta, 140, 396-403.

https://doi.org/10.1016/j.electacta.2014.04.037

[72] Ghernaout, D. (2019) Disinfection via Electrocoagulation Process: Implied Mechanisms and Future Tendencies. EC Microbiology, 15, 79-90.

[73] Ghernaout, D., Aichouni, M. and Touahmia, M. (2019) Mechanistic Insight into Disinfection by Electrocoagulation-A Review. Desalination and Water Treatment, 141, 68-81. https://doi.org/10.5004/dwt.2019.23457

[74] Rodríguez-Chueca, J., Mediano, A., Ormad, M.P., Mosteo, R. and Ovelleiro, J.L. (2014) Disinfection of Wastewater Effluents with the Fenton-Like Process Induced by Electromagnetic Fields. Water Research, 60, 250-258. https://doi.org/10.1016/j.watres.2014.04.040

[75] Ghernaout, D., Elboughdiri, N., Ghareba, S. and Salih, A. (2020) Disinfecting Water with the Carbon Fiber-Based Flow-Through Electrode System (FES): Towards Axial Dispersion and Velocity Profile. Open Access Library Journal, 7, e6238.

https://doi.org/10.4236/oalib.1106238

[76] Heffron, J., Ryan, D.R. and Mayer, B.K. (2019) Sequential Electrocoagulation Electrooxidation for Virus Mitigation in Drinking Water. Water Research, 160, 435-444. https://doi.org/10.1016/j.watres.2019.05.078

[77] Bruguera-Casamada, C., Araujo, R.M., Brillas, E. and Sirés, I. (2019) Advantages of Electro-Fenton over Electrocoagulation for Disinfection of Dairy Wastewater. Chemical Engineering Journal, 376, Article ID: 119975. https://doi.org/10.1016/j.cej.2018.09.136

[78] Ghernaout, D. and Elboughdiri, N. (2020) Urgent Proposals for Disinfecting Hospital Wastewaters during COVID-19 Pandemic. Open Access Library Journal, 7, e6373. https://doi.org/10.4236/oalib.1106373

[79] Ghernaout, D. and Elboughdiri, N. (2020) Vacuum-UV Radiation at $185 \mathrm{~nm}$ for Disinfecting Water. Chemical Science \& Engineering Research, 2, 12-17.

[80] Fan, T., Deng, W., Feng, X., Pan, F. and Li, Y. (2020) An Integrated Electrocoagulation-Electrocatalysis Water Treatment Process Using Stainless Steel Cathodes Coated with Ultrathin $\mathrm{TiO}_{2}$ Nanofilms. Chemosphere, 254, Article ID: 126776. https://doi.org/10.1016/j.chemosphere.2020.126776

[81] Ghernaout, D. and Elboughdiri, N. (2020) Disinfection By-Products: Presence and Elimination in Drinking Water. Open Access Library Journal, 7, e6140. https://doi.org/10.4236/oalib.1106140

[82] Lacasa, E., Cotillas, S., Saez, C., Lobato, J., Cañizares, P. and Rodrigo, M.A. (2019) Environmental Applications of Electrochemical Technology. What Is Needed to Enable Full-Scale Applications? Current Opinion in Electrochemistry, 16, 149-156. https://doi.org/10.1016/j.coelec.2019.07.002

[83] Ghernaout, D., Elboughdiri, N., Ghareba, S. and Salih, A. (2020) Electrochemical 
Advanced Oxidation Processes (EAOPs) for Disinfecting Water-Fresh Perspectives. Open Access Library Journal, 7, e6257. https://doi.org/10.4236/oalib.1106257

[84] Chellam, S. and Sari, M.A. (2016) Aluminum Electrocoagulation as Pretreatment during Microfiltration of Surface Water Containing NOM: A Review of Fouling, NOM, DBP, and Virus Control. Journal of Hazardous Materials, 304, 490-501. https://doi.org/10.1016/j.jhazmat.2015.10.054

[85] Ghernaout, D. and Elboughdiri, N. (2020) Environmental Engineering for Stopping Viruses Pandemics. Open Access Library Journal, 7, e6299.

[86] Cañizares, P., Jimenez, C., Martinez, F., Rodrigo, M.A. and Saez, C. (2009) The pH as a Key Parameter in the Choice between Coagulation and Electrocoagulation for the Treatment of Wastewaters. Journal of Hazardous Materials, 163, 158-164. https://doi.org/10.1016/j.jhazmat.2008.06.073

[87] Choi, J., Dorji, P., Shon, H.K. and Hong, S. (2019) Applications of Capacitive Deionization: Desalination, Softening, Selective Removal, and Energy Efficiency. Desalination, 449, 118-130. https://doi.org/10.1016/j.desal.2018.10.013

[88] Ghernaout, D. and Elboughdiri, N. (2020) Towards Enhancing Ozone Diffusion for Water Disinfection-Short Notes. Open Access Library Journal, 7, e6253. https://doi.org/10.4236/oalib.1106253

[89] Ghernaout, D. and Elboughdiri, N. (2020) $\mathrm{UV}-\mathrm{C} / \mathrm{H}_{2} \mathrm{O}_{2}$ and Sunlight $/ \mathrm{H}_{2} \mathrm{O}_{2}$ in the Core of the Best Available Technologies for Dealing with Present Dares in Domestic Wastewater Reuse. Open Access Library Journal, 7, e6161. https://doi.org/10.4236/oalib.1106161

[90] Ghernaout, D. and Elboughdiri, N. (2020) Advanced Oxidation Processes for Wastewater Treatment: Facts and Future Trends. Open Access Library Journal, 7, e6139. https://doi.org/10.4236/oalib.1106139

[91] Dai, C., Zhou, Y., Peng, H., Huang, S., Qin, P., Zhang, J., Yang, Y., Luo, L. and Zhang, X. (2018) Current Progress in Remediation of Chlorinated Volatile Organic Compounds: A Review. Journal of Industrial and Engineering Chemistry, 62, 106-119. https://doi.org/10.1016/j.jiec.2017.12.049

[92] Xu, B., Iskander, S.M. and He, Z. (2020) Dominant Formation of Unregulated Disinfection By-Products during Electrocoagulation Treatment of Landfill Leachate. Environmental Research, 182, Article ID: 109006. https://doi.org/10.1016/j.envres.2019.109006

[93] Ghernaout, D. and Elboughdiri, N. (2020) Disinfection By-Products Regulation: Zero ng/L Target. Open Access Library Journal, 7, e6382.

[94] Ghernaout, D. and Elboughdiri, N. (2020) Eliminating Cyanobacteria and Controlling Algal Organic Matter-Short Notes. Open Access Library Journal, 7, e6252.

[95] Ghernaout, D. and Elboughdiri, N. (2020) Strategies for Reducing Disinfection By-Products Formation during Electrocoagulation. Open Access Library Journal, 7, e6076. https://doi.org/10.4236/oalib.1106076

[96] Ghernaout, D. and Elboughdiri, N. (2020) Electrocoagulation Process in the Context of Disinfection Mechanism. Open Access Library Journal, 7, e6083.

[97] Ghernaout, D. (2017) Microorganisms' Electrochemical Disinfection Phenomena. EC Microbiology, 9, 160-169.

[98] Ghernaout, D. and Elboughdiri, N. (2019) Iron Electrocoagulation Process for Disinfecting Water-A Review. Applied Engineering, 3, 154-158.

[99] Ghernaout, D. and Elboughdiri, N. (2019) Electrocoagulation Process Intensification for Disinfecting Water-A Review. Applied Engineering, 3, 140-147. 
[100] Ghernaout, D. (2019) Electrocoagulation and Electrooxidation for Disinfecting Water: New Breakthroughs and Implied Mechanisms. Applied Engineering, 3, 125-133.

[101] Delaire, C., van Genuchten, C.M., Amrose, S.E. and Gadgil, A.J. (2016) Bacteria Attenuation by Iron Electrocoagulation Governed by Interactions between Bacterial Phosphate Groups and Fe(III) Precipitates. Water Research, 103, 74-82. https://doi.org/10.1016/j.watres.2016.07.020

[102] Ghernaout, D., Alghamdi, A. and Ghernaout, B. (2019) Microorganisms' Killing: Chemical Disinfection vs. Electrodisinfection. Applied Engineering, 3, 13-19.

[103] Ghernaout, D., Touahmia, M. and Aichouni, M. (2019) Disinfecting Water: Electrocoagulation as an Efficient Process. Applied Engineering, 3, 1-12.

[104] Ghernaout, D. and Elboughdiri, N. (2020) Solar Treatment in the Core of the New Disinfection Technologies. Chemical Science \& Engineering Research, 2, 6-11.

[105] Ghernaout, D. (2019) Greening Electrocoagulation Process for Disinfecting Water. Applied Engineering, 3, 27-31.

[106] Ghernaout, D. and Elboughdiri, N. (2020) Disinfecting Water: Plasma Discharge for Removing Coronaviruses. Open Access Library Journal, 7, e6314. https://doi.org/10.4236/oalib.1106314

[107] Ghernaout, D., Alghamdi, A., Touahmia, M., Aichouni, M. and Ait Messaoudene, N. (2018) Nanotechnology Phenomena in the Light of the Solar Energy. Journal of Energy, Environmental \& Chemical Engineering, 3, 1-8. https://doi.org/10.11648/j.jeece.20180301.11

[108] Ghernaout, D. and Elboughdiri, N. (2020) Controlling Disinfection By-Products Formation in Rainwater: Technologies and Trends. Open Access Library Journal, 7, e6162. https://doi.org/10.4236/oalib.1106162

[109] Ghernaout, D. and Elboughdiri, N. (2020) Electrochemical Technology for Wastewater Treatment: Dares and Trends. Open Access Library Journal, 7, e6020.

[110] Ghernaout, D. and Elboughdiri, N. (2020) Disinfection By-Products (DBPs) Control Strategies in Electrodisinfection. Open Access Library Journal, 7, e6396. https://doi.org/10.4236/oalib.1106396

[111] Ghernaout, D. and Elboughdiri, N. (2020) Foresight Look on the Disinfection By-Products Formation. Open Access Library Journal, 7, e6349. https://doi.org/10.4236/oalib.1106349

[112] Ghernaout, D., Elboughdiri, N., Alghamdi, A. and Ghernaout, B. (2020) Trends in Decreasing Disinfection By-Products Formation during Electrochemical Technologies. Open Access Library Journal, 7, e6337. https://doi.org/10.4236/oalib.1106337 